
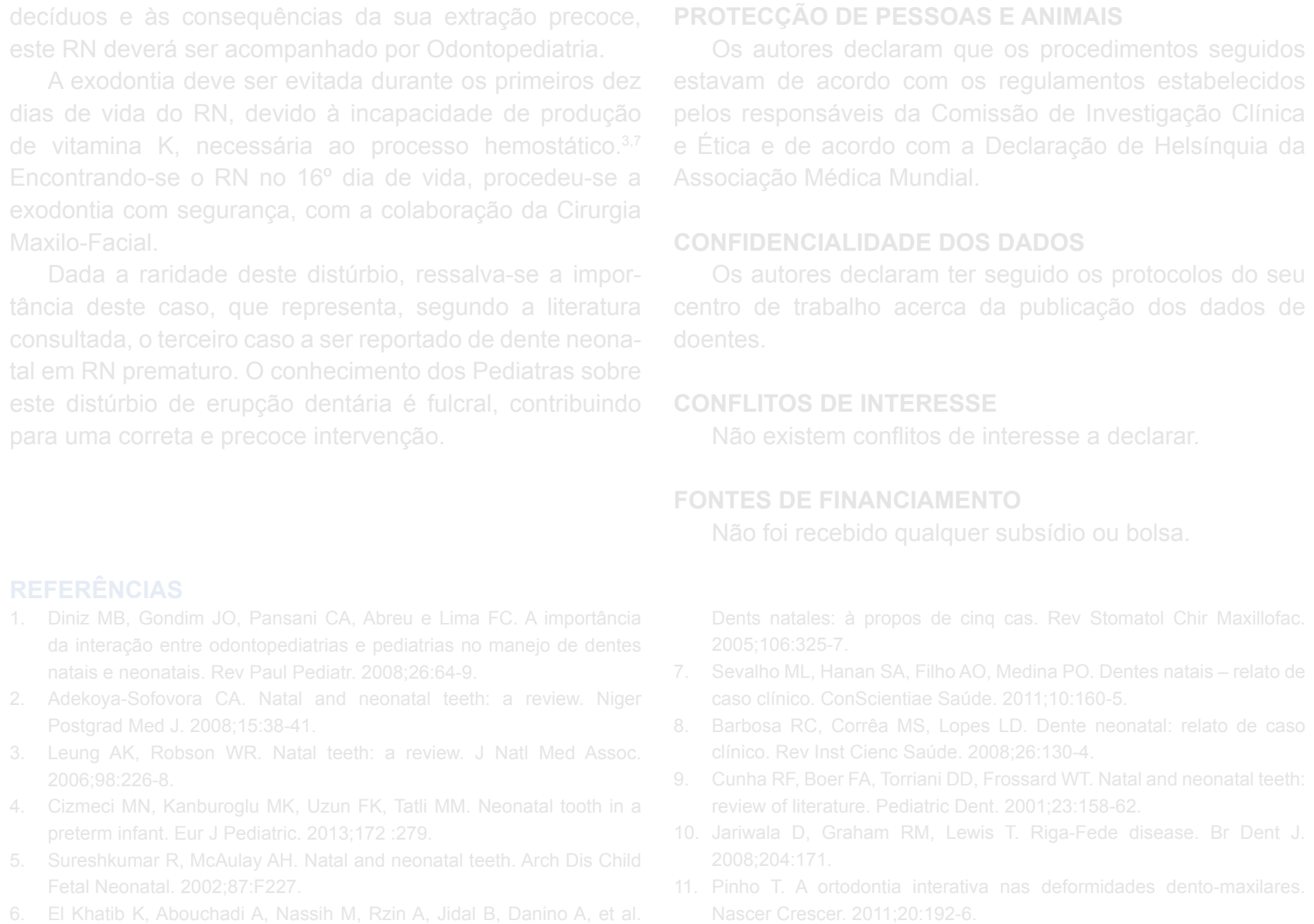

\title{
Ipilimumab-Induced Autoimmune Hypophysitis: Diagnostic and Management Challenges Illustrated by a Clinical Case
}

\author{
Hipofisite Induzida por Ipilimumab: Desafios Diagnósticos e Terapêuticos
}

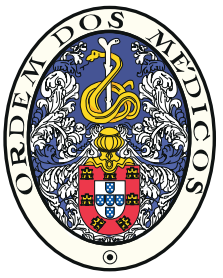

\author{
Pedro MARQUES ${ }^{1}$, Ashley GROSSMAN² \\ Acta Med Port 2015 Nov-Dec;28(6):775-779
}

\begin{abstract}
Autoimmune hypophysitis has been described in patients on ipilimumab, a humanised monoclonal antibody increasingly used in the treatment of metastatic melanoma. A 67-year-old woman presented with severe fatigue, nausea and headaches following the third dose of ipilimumab, which was being given as treatment for metastatic melanoma (four administrations at three-weekly intervals). Hormonal evaluation confirmed hypocortisolism, with low gonadotrophins and a low thyroid-stimulating hormone with normal free T4 (she was on long-standing levothyroxine because of past surgery for a multinodular goitre). Magnetic resonance imaging scanning revealed pituitary enlargement compatible with autoimmune hypophysitis. She was commenced on replacement with hydrocortisone with significant improvement of her symptoms. The enlarged pituitary was reduced in size 4 months later. The patient is currently asymptomatic on glucocorticoid and levothyroxine replacement. This case highlights relevant clinical, diagnostic and management aspects of ipilimumab-induced autoimmune hypophysitis, and emphasises the need for increasing awareness for potential side-effects of these new immunomodulatory therapies, including autoimmune hypophysitis.

Keywords: Antibodies, Monoclonal; Inflammation/chemically induced; Ipilimumab; Pituitary Diseases/chemically induced.
\end{abstract}

\footnotetext{
1. Serviço de Endocrinologia. Instituto Português de Oncologia de Lisboa. Lisboa. Portugal.

2. Department Endocrinology and Metabolism. Oxford Centre for Diabetes. Oxford. United Kingdom.

$\bowtie$ Autor correspondente: Pedro Marques. pedro.miguel.sousa.marques@gmail.com

Recebido: 21 de Abril de 2015 - Aceite: 07 de Outubro de 2015 | Copyright @ Ordem dos Médicos 2015
} 


\section{RESUMO}

A hipofisite autoimune tem sido reportada em doentes sob ipilimumab, um anticorpo monoclonal humanizado usado no tratamento do melanoma metastático. Apresenta-se o caso de uma doente do sexo feminino, 67 anos, com um quadro de fadiga, náuseas e cefaleias após a terceira dose de ipilimumab para tratamento de melanoma metastático (quatro administrações com intervalos de três semanas). A avaliação hormonal confirmou hipocortisolismo, gonadotrofinas baixas e hormona estimulante da tiróide com T4 livre normal (sob terapêutica com levotiroxina devido a cirurgia tiroideia prévia). A ressonância mangnética revelou aumento do volume hipofisário compatível com hipofisite autoimune. Iniciou-se terapêutica substitutiva com hidrocortisona oral, com melhoria sintomática. Quatro meses depois verificou-se redução do volume da hipófise. A doente está atualmente assintomática sob terapêutica com glucocorticóides e levotiroxina. Este caso ilustra aspetos clínicos, diagnósticos e terapêuticos da hipofisite autoimune induzida por ipilimumab, enfatizando a necessidade de alerta para os potenciais efeitos adversos das novas terapêuticas imunomoduladoras, entre os quais a hipofisite autoimune.

Palavra-chave: Anticorpos Monoclonais; Doenças da Hipófise/ induzido quimicamente; Inflamação/induzido quimicamente; Ipilimumab.

\section{INTRODUCTION}

Ipilimumab is a humanised monoclonal antibody that blocks cytotoxic T-lymphocyte antigen-4 (CTLA-4), an inhibitory molecule expressed on antigen-stimulated $\mathrm{T}$ cells, and thereby increases T-cell activation. ${ }^{1}$ (Fig. 1) This results in anticancer activity, well proven for certain malignancies such advanced melanoma, leading to the approval of ipilimumab in 2011 by the Food and Drug Administration and by the European Medicines Agency for unresectable or metastatic melanoma. However, its use is associated with the occurrence of immune-related adverse events (IRAEs), whose incidence is estimated at $61-77 \%^{2}$ (Table 1). Multiple endocrine abnormalities have been reported, including autoimmune hypophysitis $(\mathrm{AH})$, primary hyper/hypothyroidism and primary adrenal insufficiency. ${ }^{3}$

We present a case of ipilimumab-induced $\mathrm{AH}$, and then we discuss briefly the clinical features, diagnosis, management and follow-up of this condition.

\section{CASE REPORT}

A 67-year-old English woman who had undergone excision of a right heel melanoma in 2011, and second surgery in 2013 due to local recurrence, was identified to have metastatic liver disease in March 2014. Her medical history included a multinodular goitre requiring a left thyroid lobectomy three years before, following which she was on levothyroxine replacement therapy $(75 \mu \mathrm{g} /$ day $)$. She had no family history of any endocrinopathy or autoimmune disease.

She was offered a treatment course of ipilimumab for metastatic melanoma, which consisted of four doses (3 mg/ $\mathrm{kg}$ ) at three-weekly intervals. After the third dose, she began to complain of severe fatigue, nausea and headaches. She denied visual symptoms, polydipsia, polyuria, vomiting or other complaints. Given the severity and subacute onset of these symptoms, together with the awareness of the possible occurrence of IRAEs (namely $\mathrm{AH}$ ), hormonal evaluation was performed (Table 2); this demonstrated hypocortisolism, low gonadotrophins, a low thyroid-stimulating hormone (TSH) with a normal free T4 (she was on levothyroxine) (Table 2). Campimetry by confrontation was performed and visual

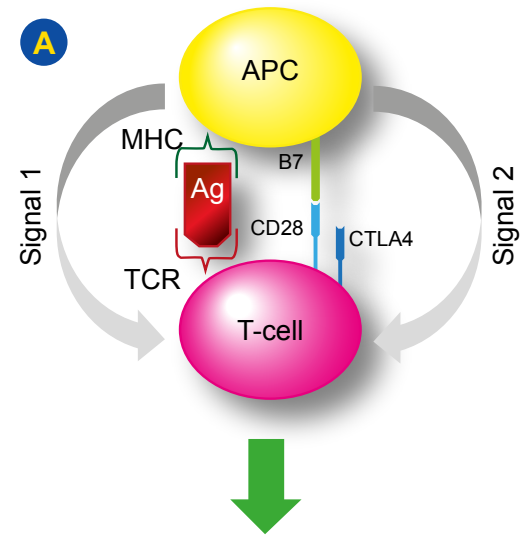

T-cell proliferation, differentiation and survival

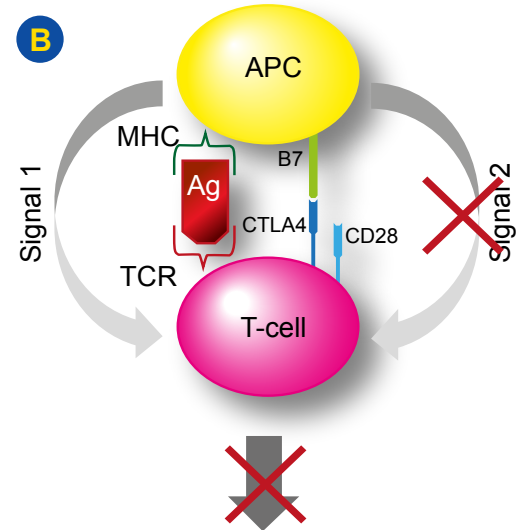

T-cell downregulation and functional inactivation

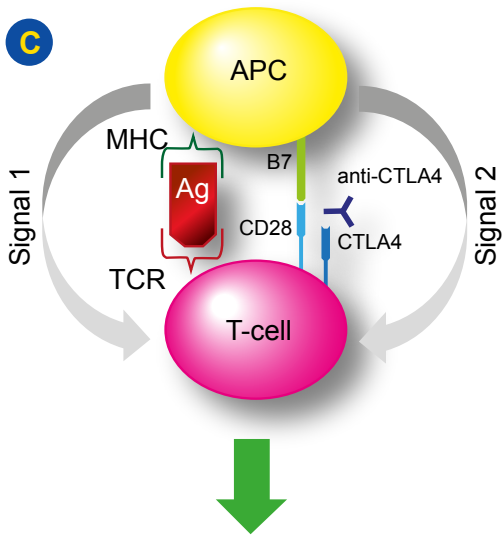

Restoration of

T-cell proliferation, differentiation and survival

Figure 1 - Mechanisms of action of CTLA- 4 and CTLA-4 inhibitors (ipilimumab)

A) The presentation of the antigen to TCR and the interaction between the stimulatory molecules B7 and CD28 are necessary for the activation of T-cells

B) The activation of T-cells upregulates CTLA-4, which in turn binds to B7 and blocks signal 2, and subsequently causes downregulation and functional inactivation of T-cells

C) Antibodies against CTLA-4 bind and block CTLA-4, allowing resumption of signal 2 and therefore, the restoration of T-cells proliferation, differentiation and survival.

APC: antigen presenting cell; MHC: major histocompatibility complex; TCR: t-cell receptor; Ag: antigen; B7: peripheral membrane protein; CTLA-4: cytotoxic t-lymphocyte antigen 4; $\mathrm{CD}$ : cluster of differentiation.

Adapted with permission: Juszczak A, Gupta A, Karavitaki N, Middleton MR, Grossman AB. Ipilimumab: a novel immonomodulating therapy causing autoimmune hypophysitis: a case report and review. Eur J Endocrinol 2012;167:1-5. 
fields were full. Magnetic resonance imaging (MRI) of the pituitary was compatible with $\mathrm{AH}$ (Fig. 2).

She was then commenced on replacement with oral hydrocortisone $(20 \mathrm{mg} /$ day in three divided doses: $10+$ $5+5 \mathrm{mg}$ ) with significant improvement of her symptoms. The patient has received her fourth dose of ipilimumab with no further problems. Currently, she is on thyroxine and glucocorticoid replacement (8 months after ipilimumab), and the enlarged pituitary is now reduced in size in the MRI scan performed 4 months later (Fig. 2).

\section{DISCUSSION}

We report a case of ipilimumab-induced $\mathrm{AH}$. $\mathrm{AH}$ is a rare condition, but with increasing frequency following the use of new immunomodulatory drugs. ${ }^{4}$ In an advanced melanoma setting, recent series have estimated the incidence of ipilimumab-induced $\mathrm{AH}$ at approximately $11 \%-13 \%{ }^{5-7}$ Variation in the reported incidences may be explained by different doses of ipilimumab, concomitant drugs, intensity of hormonal monitoring, and different clinical awareness or suspicion for $\mathrm{AH}^{8}$ Male gender and older age are possible risk factors for its occurrence. ${ }^{6,7}$ The onset of ipilimumabinduced $\mathrm{AH}$ normally occurs 6 - 12 weeks after the initiation of ipilimumab (on average 9 weeks), frequently after the third infusion, ${ }^{2,5,7}$ as seen in this patient.

Patients who develop ipilimumab-induced $\mathrm{AH}$ may be present with non-specific symptoms such fatigue, weakness, nausea, vomiting, insomnia, decreased libido, headaches, often masked by the underlying oncological condition. ${ }^{2} \mathrm{~A}$ high index of suspicion is required to promptly proceed to its evaluation, which should include assessment of anterior pituitary function (ACTH and morning serum cortisol, a tetracosactide (Synacthen) stimulation test, free T4, TSH, $\mathrm{LH}, \mathrm{FSH}$, testosterone/oestradiol, IGF-1 and prolactin) and an MRI scan. ${ }^{2,3,9,10}$ There is no reliable serologic test available to aid/make the diagnosis of ipilimumab-induced $\mathrm{AH}$, although it is presumed that pituitary antibodies may be involved. ${ }^{11}$ Currently, this diagnosis is best made based on clinical suspicion (including the chronological relation with ipilimumab), laboratory evaluation of pituitary function and a consistent MRI. ${ }^{11}$

The corticotrophs and thyrotrophs are apparently more vulnerable to ipilimumab because ACTH and TSH secretion seems to be invariably lost in most cases, followed by the loss of $\mathrm{FSH}, \mathrm{LH}$ and occasionally $\mathrm{GH}$, although $\mathrm{GH}$ deficiency may not be so frequently assessed. Prolactin can be suppressed or elevated (in cases of stalk compression), and diabetes insipidus rarely occurs. ${ }^{2,7}$ The resultant hypocortisolism and hypothyroidism is life-threatening, requiring immediate replacement therapy. ${ }^{2,7,10}$ In this patient, low cortisol was documented; the involvement of the gonadotrophin axis was suggested by the low concentrations of gonadotrophins, contrary to what is expected for a menopausal women; the thyroid axis was more difficult to evaluate as the patient was already on thyroxine following the thyroid surgery.

In most cases, up to $60 \%-100 \%$, MRI reveals diffuse pituitary enlargement, with thickening of the stalk. The height of pituitary may increase modestly, from $3.4 \mathrm{~mm}$ $6.0 \mathrm{~mm}$ to $7.7 \mathrm{~mm}-11.8 \mathrm{~mm} .^{1,11-13}$ Pituitary enlargement is a highly sensitive indicator of ipilimumab-induced $\mathrm{AH}$ and may cause compression of optic chiasm and visual defects,

Table 1 - Possible immune-related adverse events (IRAEs) in patients on ipilimumab

Autoimmune hypophysitis; thyroiditis; primary adrenal insufficiency

Gastritis; enteritis; colitis; hepatitis

Iritis; uveitis; episcleritis

Dermatitis; pruritus; rash; vitiligo; alopecia areata

Arthritis; tubulointerstitial nephritis; red cell aplasia; aseptic meningitis; alveolitis

Table 2 - Hormonal findings at the diagnosis of ipilimumab-induced hypophysitis

\begin{tabular}{lll}
\hline Test & Result & Reference range \\
\hline Serum cortisol & 12 & $<100 \mathrm{nmol} / \mathrm{L}$ suggests adrenal insufficiency \\
$\begin{array}{l}\text { Short Synacthen test (SST) } \\
\text { Baseline (1 pm) }\end{array}$ & $<22$ & Normal SST: \\
$\mathbf{3 0 ~}$ min & 126 & serum cortisol $(30 \mathrm{~min})>550 \mathrm{nmol} / \mathrm{L}$ \\
LH & 3.8 & $30-200 \mathrm{IU} / \mathrm{L}$ \\
FSH & 12.3 & $>40 \mathrm{IU} / \mathrm{L}$ for menopausal women \\
TSH & 0.35 & $0.35-5.5 \mathrm{mU} / \mathrm{L}$ \\
Free T4 & 12.9 & $10.5-20 \mathrm{pmol} / \mathrm{L}$ \\
IGF-1 & 21.3 & $4.5-22.5 \mathrm{nmol} / \mathrm{L}$ \\
Prolactin & 350 & $60-620 \mathrm{mU} / \mathrm{L}$ \\
\hline
\end{tabular}



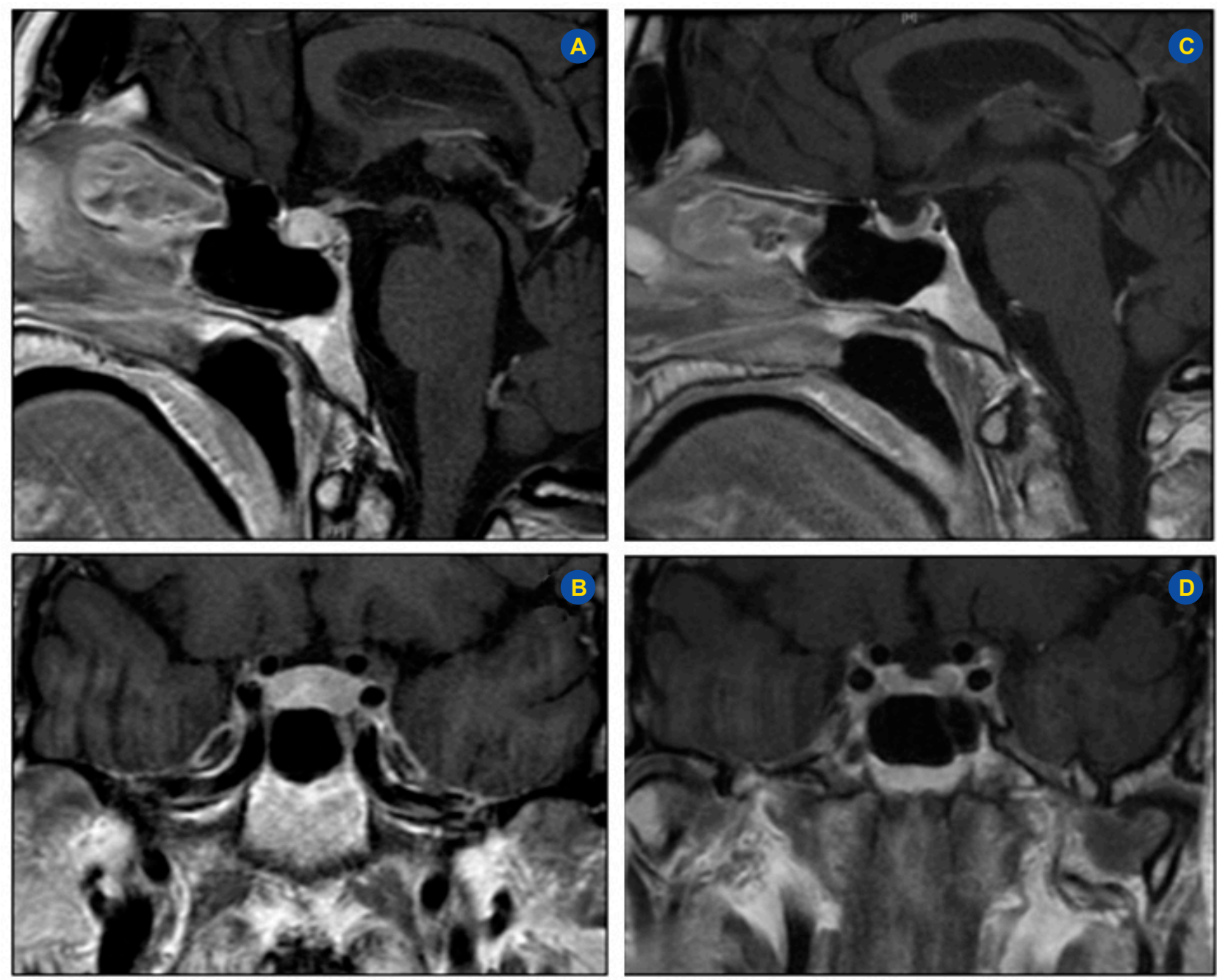

Figure 2 - Pituitary MRI scans at diagnosis of ipilimumab-induced autoimmune hypophysitis (A,B) and four months after (C,D)

A/B) MRI scan at diagnosis: the overall volume of the pituitary gland is increased and the gland has a superiorly convex border. A slight increase of the pituitary stalk thickness is seen. These features are compatible with autoimmune hypophysitis.

C/D) MRI scan 4 months after the diagnosis of ipilimumab-induced hypophysitis: the pituitary gland has reduced in volume, showing a superior concave margin and it is slightly atrophic. The pituitary stalk is on the midline with normal appearance.

although this situation is rarely seen., ${ }^{2,6,7}$ A metastatic lesion must be considered in patients with malignant melanoma with evidence of pituitary enlargement (with or without hypopituitarism). The absence of diabetes insipidus and the improvement following glucocorticoids is suggestive of $\mathrm{AH}$; continuous growth despite corticosteroids favours the hypothesis of metastatic lesion. Although a biopsy is the gold standard to differentiate these two entities, it is rarely needed as the clinical behaviour, MRI findings, response to therapy and follow-up reassessments allow an accurate diagnosis in the majority of the cases. ${ }^{2}$ Pituitary MRI may also be normal in some cases of ipilimumab-induced $\mathrm{AH}^{11-}$ 13

The management of ipilimumab-induced $\mathrm{AH}$ is controversial. Ipilimumab-induced $\mathrm{AH}$ has been managed with initial high-dose of glucocorticoids, but some authors have questioned this approach. $1,6,7,14,15$ In a recent study, systemic high-dose of corticosteroids did not improve the outcomes (resolution frequency and time to resolution) and slightly decreased overall survival, ${ }^{7}$ raising the concern that high-dose of glucocorticoids may affect the anti-tumoural efficacy of ipilimumab ${ }^{1,6,7}$ and suggesting that this approach may not be indicated. ${ }^{1,7}$ Instead, hormonal replacement therapy, including glucocorticoids or other hormones which are deficient, seem more appropriate in the absence of severe headaches and/or substantial pituitary enlargement, or other significant IRAEs. ${ }^{6,7}$ Another debated topic is whether or not to interrupt ipilimumab in patients who develop $\mathrm{AH}$. The current evidence, in terms of efficacy and safety of ipilimumab in this setting, favours its continuation/ re-initiation in order to treat the underlying malignant disease. ${ }^{1,2,6}$ The occurrence of IRAEs may be even associated with greater anti-tumoural efficacy, reinforcing the benefit of its continuation. ${ }^{6,14,15}$ Nevertheless, in severe IRAEs, it may be reasonable to temporarily interrupt ipilimumab. ${ }^{6}$ This case was successfully managed with physiological glucocorticoid replacement, and ipilimumab treatment was not interrupted. 
Recovery of the pituitary thyroid axis has been reported in $37-50 \%$, whereas gonadal axis may recover in over $50 \%$ of cases. ${ }^{2,12}$ Corticotroph function appears to be persistently affected, so very few patients might be able to discontinue glucocorticoid replacement., ${ }^{2,7}$ Pituitary hormone deficiencies should be periodically re-evaluated after the radiological resolution of $\mathrm{AH} .{ }^{6}$ MRI-based studies showed that enlarged pituitaries tend to normalise in size in a variable period of time (4-12 weeks), independent of the type of glucocorticoid therapeutic approach (replacement/ high-dose). ${ }^{1,2,7,11}$ In this case there was no recovery of the pituitary function, and therefore the patient remains on glucocorticoid replacement.

The case reported highlights relevant clinical, diagnostic and management aspects of ipilimumab-induced $\mathrm{AH}$ and emphasises the importance for clinicians to be aware of potential side-effects of the new immunomodulatory therapies, including $\mathrm{AH}$, which can adversely affect the patient's quality life or even be life-threatening, if unrecognised.

\section{REFERENCES}

1. Juszczak A, Gupta A, Karavitaki N, Middleton MR, Grossman AB. Ipilimumab: a novel immonomodulating therapy causing autoimmune hypophysitis: a case report and review. Eur J Endocrinol. 2012;167:15

2. Corsello SM, Barnabei A, Marchetti P, Vecchis L, Salvatori R, Torino F. Endocrine side effects induced by immune checkpoint inhibitors. J Clin Endocrinol Metab. 2013;98:1361-75.

3. Dillard T, Yedinak CG, Alumkal J, Fleseriu M. Anti-CTLA-4 antibody therapy associated autoimmune hypophysitis: serious immune related adverse events across a spectrum of cancer subtypes. Pituitary. 2010;13:29-38.

4. Falorni A, Minarelli V, Bartoloni E, Alunno A, Gerli R. Diagnosis and classification of autoimmune hypophysitis. Autoimmun Rev. 2014;13:412-6.

5. Albarel F, Gaudy C, Castinetti F, Carré T, Morange I, Conte-Devolx $B$, et al. Long-term follow-up of ipilimumab-induced hypophysitis, a common adverse event of the anti-CTLA-4 antibody in melanoma. Eur J Endocrinol. 2015;172:195-204.

6. Faje AT, Sullivan R, Lawrence D, Tritos NA, Fadden R, Klibanski A, et al. Ipilimumab-induced hypophysitis: a detailed longitudinal analysis in a large cohort of patients with metastatic melanoma. J Clin Endocrinol Metab. 2014;99:4078-85.

7. Min L, Hodi FS, Giobbie-Hurder A, Ott PA, Luke JJ, Donahue H, et al. Systemic high-dose corticosteroid treatment does not improve the outcome of ipilimumab-related hypophysitis: a retrospective cohort study. Cancer Res. 2014;21;749-55.

8. Torino F, Barnabei A, Paragliola RM, Marchetti P, Salvatori R, Corsello

\section{PROTECTION OF HUMANS AND ANIMALS}

The authors declare that the study was approved by the Ethics Committee of the Hospital and that the described procedures followed the regulations established by the Clinical Research and Ethics Committee and to the Helsinki Declaration of the World Medical Association.

\section{DATA CONFIDENTIALITY}

The authors declare that they followed the protocols in use at their working center regarding patient's data publication.

\section{CONFLICTS OF INTEREST}

The authors declare that there are no conflicts of interest.

\section{FUNDING SOURCES}

No subsidies or grants contributed to this work.

SM. mAbs and pituitary dysfunction: clinical evidence and pathogenic hypotheses. Eur J Endocrinol. 2013;169:R153-64.

9. Scarpati G, Fusciello C, Perri F, Sabbatino F, Ferrone S, Carlomagno $\mathrm{C}$, et al. Ipilimumab in the treatment of metastatic melanoma: management of adverse events. Onco Targets Ther. 2014;7:203-9.

10. Min L, Vaidya A, Becker C. Association of ipilimumab therapy for advanced melanoma with secondary adrenal insufficiency: a case series. Endocr Pract. 2012;18:351-5.

11. Chodakiewitz Y, Brown S, Bowerman JL, Brody JM, Rogg JM. Ipilimumab treatment associated pituitary hypophysitis: clinical presentation and imaging diagnosis. Clin Neurol Neurosurg. 2014;125:125-30.

12. Blansfield JA, Beck KE, Tran K, Yang JC, Hughes MS, Kammula US, et al: Cytotoxic T-lymphocyte-associated antigen 4-blockage can induce autoimmune hypophysitis in patients with metastatic melanoma and renal cancer. J Immunother. 2005;28:593-8.

13. Carpenter KJ, Murtagh RD, Lilienfeld $\mathrm{H}$, Weber J, Murtagh FR. Ipilimumab-induced hypophysitis: MR imaging findings. Am J Neuroradiol. 2009;30:1751-3.

14. Weber JS, Kahler KC, Hauschild A. Management of immune-related adverse events and kinetics of response with ipilimumab. J Clin Oncol. 2012;30:2691-7.

15. Tiu C, Pezaro C, Davis ID, Grossmann M, Parente P. Early recognition of ipilimumab-related autoimmune hypophysitis in patients with metastatic melanoma: case studies and recommendations for management. Asia Pac J Clin Oncol. 2015;11:190-4. 


\section{Ipilimumab-Induced Autoimmune Hypophysitis: Diagnostic and Management Challenges Illustrated by a Clinical Case}

Acta Med Port 2015:28:775-779

Publicado pela Acta Médica Portuguesa, a Revista Científica da Ordem dos Médicos

Av. Almirante Gago Coutinho, 151

1749-084 Lisboa, Portugal.

Tel: +351218428215

E-mail: submissao@actamedicaportuguesa.com

www.actamedicaportuguesa.com

ISSN:0870-399X | e-ISSN: 1646-0758

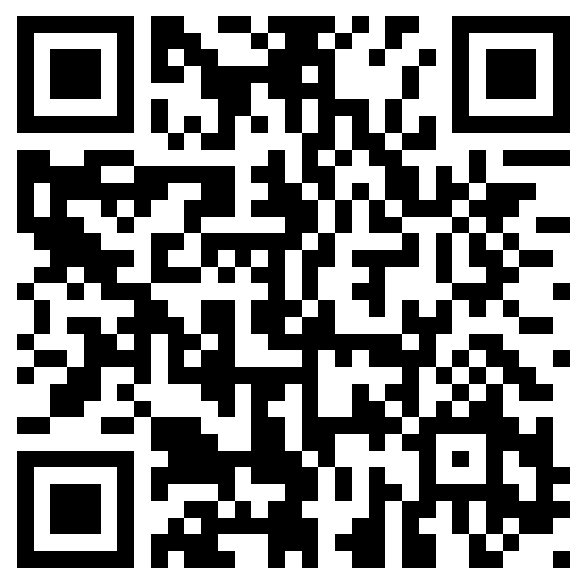

